Nova Southeastern University

Florida

\author{
Nova Southeastern University
}

NOVA SOUTHEASTERN

UNIVERSITY

NSUWorks

Marine \& Environmental Sciences Faculty

Articles

Department of Marine and Environmental

Sciences

$1-19-2021$

\title{
Late afternoon seasonal transition to dissolution in a coral reef: An early warning of a net dissolving ecosystem?
}

\author{
Laura Stoltenberg \\ Southern Cross University \\ Kai G. Schulz \\ Southern Cross University \\ Coulson A. Lantz \\ Southern Cross University \\ Tyler Cyronak \\ Nova Southeastern University, tcyronak@nova.edu \\ Bradley D. Eyre \\ Southern Cross University \\ Find out more information about Nova Southeastern University and the Halmos College of \\ Follow this and additional works at: https://nsuworks.nova.edu/occ_facarticles \\ Natural Sciences and Oceanography. \\ Part of the Marine Biology Commons, and the Oceanography and Atmospheric Sciences and
}

Meteorology Commons

This Article has supplementary content. View the full record on NSUWorks here:

https://nsuworks.nova.edu/occ_facarticles/1137

\section{NSUWorks Citation}

Laura Stoltenberg, Kai G. Schulz, Coulson A. Lantz, Tyler Cyronak, and Bradley D. Eyre. 2021. Late afternoon seasonal transition to dissolution in a coral reef: An early warning of a net dissolving ecosystem? .Geophysical Research Letters : e2020GL090811 . https://nsuworks.nova.edu/ occ_facarticles/1137.

This Article is brought to you for free and open access by the Department of Marine and Environmental Sciences at NSUWorks. It has been accepted for inclusion in Marine \& Environmental Sciences Faculty Articles by an authorized administrator of NSUWorks. For more information, please contact nsuworks@nova.edu. 
Late afternoon seasonal transition to dissolution in a coral reef: An early warning of a net dissolving ecosystem?

Laura Stoltenberg $^{1 *}$, Kai G. Schulz ${ }^{1}$, Coulson, A. Lantz ${ }^{1}$, Tyler Cyronak ${ }^{2}$, Bradley D. Eyre ${ }^{1}$

${ }^{1}$ Centre for Coastal Biogeochemistry Research, Southern Cross University, Lismore, NSW 2480, Australia

${ }^{2}$ Halmos College of Natural Science and Oceanography, Nova Southeastern University, Dania Beach, Florida, USA

*laurastolten@gmail.com

Key points:

1. Ecosystem calcification and sediment calcification on Heron Island reef exceed dissolution such that NEC remains largely positive.

2. Shallow, calcium carbonate $\left(\mathrm{CaCO}_{3}\right)$ sediments contribute $8-12 \%$ of reef NEC during the day and at least $45-78 \%$ of reef NEC at night.

3. The seasonal shifts to negative net ecosystem calcification before dusk may be a precursor of periodic net ecosystem dissolution.

This article has been accepted for publication and undergone full peer review but has not been through the copyediting, typesetting, pagination and proofreading process, which may lead to differences between this version and the Version of Record. Please cite this article as doi: 10.1029/2020GL090811.

This article is protected by copyright. All rights reserved. 


\section{ABSTRACT}

There are concerns that reefs will transition from net calcifying to net dissolving in the near future due to decreasing calcification and increasing dissolution rates. Here we present in situ rates of net ecosystem calcification (NEC) and net ecosystem production (NEP) on a coral reef flat using a slack-water approach. Up until dusk, the reef was net calcifying in most months but shifted to net dissolution in austral summer, coinciding with high respiration rates and a lower aragonite saturation state $\left(\Omega_{\text {arag }}\right)$. The estimated sediment contribution to NEC ranged from $8-21 \%$ during the day and $45-78 \%$ at night, indicating that high rates of sediment dissolution may cause the transition to reef dissolution. This late afternoon seasonal transition to negative NEC may be an early warning sign of the reef shifting to a net dissolving state and may be occurring on other reefs.

\section{Plain language summary}

Positive rates of net ecosystem calcification and net ecosystem production are regarded as fundamental to the healthy functioning of coral reef ecosystems. In particular, positive ecosystem calcification is required to maintain the structural complexity that sustains many of the ecosystem functions of coral reefs. While most reefs are currently net calcifying, there is growing concern that increased pressures from rising sea surface temperatures and reductions in ocean surface $\mathrm{pH}$ (ocean acidification $(\mathrm{OA})$ ) will both depress coral calcification and increase dissolution. This could result in a shift of the whole ecosystem closer to a state of net dissolution before the end of the century. Here, we measured hourly afternoon rates of net ecosystem calcification and production on a coral reef flat over ten months of the year. We found that the reef flat was already showing signs of net dissolution during certain times of the year (austral summer), which may become more extreme under global climate change. These temporary shifts in coral reef metabolism may provide insight 
into how the ecosystem will respond to future, more persistent periods of net dissolution driven by OA.

Keywords: coral reef metabolism, dissolution, community calcification, Great Barrier Reef, calcium carbonate, ocean acidification

This article is protected by copyright. All rights reserved. 


\section{1.) Introduction}

Rising sea surface temperatures and declining surface ocean $\mathrm{pH}$ (ocean acidification OA) are impacting coral reefs on local, regional, and global scales, leading to a reduction in coral cover [Gardner et al., 2003; Hughes et al., 2018; Perry et al., 2018] and declining calcification rates [Cooper et al., 2008; Pisapia et al., 2019]. Net ecosystem calcification (NEC), or the balance between calcium carbonate production and dissolution, is regarded as one of the four cornerstones of coral reef functioning [Brandl, 2019]. Positive NEC is directly related to habitat provision and structural complexity, which is crucial for maintaining desirable reef attributes such as resilience and ecosystem services [Brandl, 2019; Graham and Nash, 2013]. Net ecosystem calcification has been shown to decrease significantly with decreasing seawater $\mathrm{pH}$ and aragonite saturation state $\left(\Omega_{\mathrm{arag}}\right)$ [Albright et al., 2018; Doo et al., 2019], and the observed effect in situ is often much larger than those predicted based on laboratory or mesocosm studies [Carpenter et al., 2018; Reynaud et al., 2003]. A large proportion of the decline in NEC associated with experimental ocean acidification might be due to increases in calcium carbonate dissolution [Andersson et al., 2009; Comeau et al., 2015], which is most likely occurring in reef sediments and framework [Eyre et al., 2014]. Teasing apart the relative impacts of constructive processes (e.g., biogenic calcification) versus the destructive process of dissolution on changes in NEC under ocean acidification remains a critical problem for assessing the tipping points of coral reefs into a state of net calcium carbonate loss [Alvarez-Filip et al., 2009].

On any given reef, NEC represents the combined contributions of all calcifying organisms (including corals, calcifying algae, mollusks, benthic foraminifera, and sediment infauna and associated microbes), plus some level of inorganic calcium carbonate $\left(\mathrm{CaCO}_{3}\right)$ precipitation/dissolution occurring within the sediments and framework [Burdige et al., 2010; Courtney et al., 2016; Webb, 2001; Wurgaft et al., 2016]. The largest contribution to NEC 
most likely comes from organisms such as corals and calcifying algae, largely due to their disproportionally high rates of calcification. Even though sediments tend to have lower rates of net community calcification ( $\mathrm{NCC}_{\text {sediments }}$ ), they could also be an important component of $\mathrm{NEC}_{\text {reef }}$ due to their large benthic habitat coverage [Gattuso et al., 1998]. For example, sediments could be responsible for up to $50 \%$ of NEC for the Heron Island reef flat [Cyronak and Eyre, 2016]. $\mathrm{NCC}_{\text {sediments }}$ is expected to decline with ocean acidification at an order of magnitude greater rate than biogenic calcification [Cyronak et al., 2013; Eyre et al., 2018]. Based on previously published fluxes and the large areal extent of coverage, sediments could represent a significant contribution to coral reef NEC and play an important role in the response of reef ecosystems to ocean acidification.

Over a diel cycle, coral reefs and sediments are typically net calcifying (positive NEC) during the day and net dissolving (negative NEC) at night. Generally, daytime calcification exceeds nighttime dissolution, resulting in positive NEC over 24 hours [McMahon et al., 2013; Stoltenberg et al., 2019]. There are some exceptions to this; for example, in the Gulf of Eilat, Red Sea, the reef maintained positive NEC throughout the night [Silverman et al., 2007] and a barrier reef flat in Hawaii was net dissolving at night in only about half of the measurements [Shamberger et al., 2011]. In contrast, some reefs and reef sediments already show seasonal net dissolution [Eyre et al., 2018; Meléndez et al., 2018; Muehllehner et al., 2016; Stoltenberg et al., 2019]. Periods of net dissolution have been attributed to instances of very high cloud cover and turbidity [Takeshita et al., 2016; Yates and Halley, 2006] regional acidification events [Yeakel et al., 2015] or when the reef is net heterotrophic (e.g., negative net ecosystem production; NEP) [Bates et al., 2009, 2010; McMahon et al., 2013]. In contrast, high NEC is often related to periods of increased NEP that alter the carbonate chemistry in favor of calcification [Bates et al., 2009]. Based on these 
observations, the first instances of shifts to negative NEC are likely to occur at nighttime and then shift to early mornings and late afternoons as conditions change that favor dissolution.

There are a few in situ measurements of reef NEC that cover diel and/or seasonal cycles but none of them have specifically looked at the transition between daytime calcification and nighttime dissolution [Albright et al., 2015; Davis et al., 2019; DeCarlo et al., 2017;

McMahon et al., 2013; McMahon et al., 2018; McMahon et al., 2019; Shamberger et al., 2011; Shaw et al., 2014; Silverman et al., 2007; Silverman et al., 2012]. We hypothesize that this boundary varies seasonally, in line with a range of environmental parameters such as irradiance, $\Omega_{\text {arag, }}$, and temperature. We measured NEC over a seasonal cycle at Heron Island (Great Barrier Reef), and specifically targeted the afternoon hours to detect the shift between net calcification and dissolution. In addition, we estimated the contribution of $\mathrm{NCC}_{\text {sediments }}$ to whole reef NEC during both day and night to better understand the drivers of reef NEC, its temporal variation, and potential response to future ocean conditions.

\section{2.) Methods}

Study site

This study was conducted on Heron Island $\left(23^{\circ} 27^{\prime} \mathrm{S}, 151^{\circ} 55^{\prime} \mathrm{E}\right)$ between October 2015 and November 2016. Heron Island is a lagoonal platform reef situated at the southern end of the Great Barrier Reef, Australia, and covers an area of $\sim 0.16 \mathrm{~km}^{2}$, with a lagoon and reef flat extending over $26.4 \mathrm{~km}^{2}$ (Figure S1). The study site was located within the inner reef flat on a sandy patch, approximately $100 \mathrm{~m}$ off the beach, interspaced with patches of coral. Most of the lagoon and reef flat is covered in $\mathrm{CaCO}_{3}$ sediments with $68.2 \%$ sand found on the inner reef flat [Allen Coral Atlas, 2019]. Average water depth of the reef flat is $1.1 \mathrm{~m}$, with a semi-diurnal tidal cycle and range of 0.3-2.6 m [Kline et al., 2019].

Discrete sampling and processing

This article is protected by copyright. All rights reserved. 
Approximately every six weeks, discrete water samples were taken to measure total alkalinity (TA), dissolved inorganic carbon (DIC), and dissolved inorganic nutrients (nitrate and nitrite $\left[\mathrm{NO}_{\mathrm{X}}\right]$, phosphate $\left[\mathrm{PO}_{4}{ }^{3-}\right]$ and ammonium $\left.\left[\mathrm{NH}_{4}{ }^{+}\right]\right)$. All samples were taken using a plastic syringe which was flushed with sea water three times. Samples for DIC and TA were gently filtered ( $0.45 \mu \mathrm{m}$ cellulose acetate syringe filters) into borosilicate glass bottles filled from the bottom using a silicone tube and allowed to overflow. Sample collection bracketed the low tide while the reef flat was isolated from the surrounding ocean, with one sample collected every hour for a total of four samples per low tide (14:30 - 18:30; or $4 \mathrm{~h}$ from sunset to $1 \mathrm{~h}$ after sunset). A total of 40 samples were collected for 10 low tides from October 2015 to November 2016. In order to capture a composite diurnal cycle, we also sampled at different times of the day during low tide between $11-21$ November 2016 ( $\mathrm{n}=9$ low tides) using the same methods described above. The remaining carbonate chemistry parameters $\left(\mathrm{pH}_{\mathrm{T}}, f \mathrm{CO}_{2}, \Omega_{\mathrm{arag}}\right)$ were calculated using CO2SYS in MATLAB [van Heuven et al., 2011], with in situ temperature and salinity, and equilibrium constants from Mehrbach et al. [1973] refit by Dickson and Millero [1987].

\section{Reef metabolism calculations}

Due to its geomorphology, the Heron Island reef flat becomes isolated from offshore waters at low tide, allowing for a slack-water approach to calculate NEC and NEP from TA and DIC measurements using equations (1) and (2) [Kinsey, 1978; Langdon et al., 2010].

This approach assumes that changes in water chemistry are directly caused by the biological activity of the benthic communities, with minimal influence from water column processes.

$$
\begin{aligned}
& N E C=-\frac{0.5 \Delta T A d \rho}{\Delta t} \\
& N E P=-\frac{(\Delta D I C-0.5 \Delta T A) d \rho}{\Delta t}-F_{C O 2}
\end{aligned}
$$

where $\Delta \mathrm{TA}$ and $\triangle \mathrm{DIC}$ are the change in TA and DIC between sampling pairs, $\mathrm{d}$ is the average water depth $(\mathrm{m})$ between sampling points, $\rho$ is the sea water density $\left(\mathrm{kg} \mathrm{m}^{-3}\right)$

This article is protected by copyright. All rights reserved. 
calculated using in situ temperature and salinity, $\Delta \mathrm{t}$ is the sampling interval between two samples $(\mathrm{h})$, and $\mathrm{F}_{\mathrm{CO} 2}\left(\mathrm{mmol} \mathrm{m}{ }^{-2} \mathrm{~h}^{-1}\right)$ is the air-sea flux of $\mathrm{CO}_{2}$. Further details on the approach, calculations, and statistical analysis can be found in the supplementary material.

\section{3.) Results}

\section{Temporal variability in environmental data}

A nested ANOVA showed that $\Omega_{\text {arag }}$ was significantly different in certain months of the year, with low $\Omega_{\text {arag }}$ in December 2015 and November $2016(\mathrm{~F}=5.513$, df $=9, \mathrm{p}=0.013$, Figure S4). Mean monthly temperature ranged between $20.6^{\circ} \mathrm{C}$ in austral winter to $26.5^{\circ} \mathrm{C}$ in austral summer (Table $\mathrm{S} 1$ ), while mean $\mathrm{pH}$ and salinity exhibited little seasonal variation. Light showed a clear seasonal trend with highest daily irradiance in spring and summer (47.6 to $44.8 \mathrm{~mol}$ photons $\left.\mathrm{m}^{-2} \mathrm{~d}^{-1}\right)$ and about half in winter $\left(27.9 \mathrm{~mol}\right.$ photons $\left.\mathrm{m}^{-2} \mathrm{~d}^{-1}\right)$. A principal component analysis (PCA) showed that along the first principal component (PC1) $28.7 \%$ of the variability can be explained by the combination of instantaneous irradiance, hours until sunset, NEC, and NEP (Figure S3). On the second principal component (PC2) $19.7 \%$ of variability is explained $\mathrm{pH}, \mathrm{NO}_{\mathrm{x}}$, which were positively correlated to each other and negatively correlated to temperature and mean irradiance and daily integrated irradiance.

\section{Diurnal and seasonal variability in reef NEC and NEP}

For monthly rates between 14:30 and 18:30, corresponding to 4 hours before sunset to one hour after sunset, NEC and NEP generally declined over time (Figure 1). NEC remained positive up to sunset, with the notable exceptions of December 2015 and November 2016 where NEC shifted to negative (i.e., net reef dissolution) and no longer calcifying in February 2016 (Figure 1). NEP and NEC were highly correlated $(\mathrm{R}=0.896 \mathrm{p}<0.0001, \mathrm{n}=31$, Figure S6). The transition to net respiration between $30 \mathrm{~min}$ and $1 \mathrm{~h}$ from sunset was consistent throughout the year, with the exception of May 2016, which had very high rates of NEP (Figure 1). NEC and NEP were fit to PAR with a polynomial function which represented the 
best fit (Figure S7). NEC was also significantly correlated to $\Omega_{\text {arag }}(\mathrm{R}=0.548, \mathrm{p}=0.002, \mathrm{n}=$ 28, Figure S8). No correlation of NEP or NEC with temperature was found (Figure S9).

In the November 2016 diel cycle, NEC ranged between -4.3 and $21.5 \mathrm{mmol} \mathrm{CaCO}_{3}$ $\mathrm{m}^{-2} \mathrm{~h}^{-1}$ with average daytime NEC of $8.3 \pm 4.3 \mathrm{mmol} \mathrm{m}^{-2} \mathrm{~h}^{-1}$ and nighttime NEC of $-1.7 \pm 2.7$ mmol $\mathrm{m}^{-2} \mathrm{~h}^{-1}$. NEP had a larger amplitude than NEC and ranged between -35.1 and 48.6 mmol m $\mathrm{m}^{-2} \mathrm{~h}^{-1}$ (Figure S5). Average daytime NEP was $25.3 \pm 10.2 \mathrm{mmol} \mathrm{C}^{-2} \mathrm{~h}^{-1}$ and average nighttime NEP was $-13.4 \pm 11.1 \mathrm{mmol} \mathrm{m}^{-2} \mathrm{~h}^{-1}$. Integrated NEC and NEP remained positive during the day and negative at night, with positive NEC and NEP maintained over $24 \mathrm{~h}$ (Table S2).

\section{4.) Discussion}

\section{NEC seasonality and transition to net $\mathrm{CaCO}_{3}$ dissolution}

Integrated rates of day and night NEC from the November 2016 diel cycle show that the reef maintains net calcification during the day and over $24 \mathrm{~h}$. Based on what we know from a typical diel cycle, it is likely that Heron Island reef flat maintains a state of net $\mathrm{CaCO}_{3}$ accretion over an annual cycle. This is further supported by a positive carbonate budget recently estimated for Heron Island [Brown et al., 2020]. Our integrated NEC and NEP rates were similar to previous in situ studies of reef metabolism at this site (Table S2). Recent reviews on coral reef NEC suggest that the majority of reefs show positive net NEC [Courtney and Andersson, 2019; DeCarlo et al., 2017]. There are, however, reef systems that are presently no longer net calcifying, or already net dissolving. For example, Enrique forereef and off-reef areas are net dissolving year-round with active $\mathrm{CaCO}_{3}$ accretion only occurring between January to mid-April, with net heterotrophy being the primary driver of $\mathrm{CaCO}_{3}$ dissolution [Melendez et al., 2018]. Similarly, across the Caribbean, many reefs are no longer contributing to the net production of $\mathrm{CaCO}_{3}$ due to declining coral cover [Perry et al., 2018]. While informative, these $\mathrm{CaCO}_{3}$ budgets can miss finer details, including the 
transition to net dissolution over diel or seasonal time scales. Many $\mathrm{CaCO}_{3}$ budget studies don't include the contribution of sediment dissolution to net ecosystem dissolution, with some notable exceptions [Courtney et al. 2016; Brown et al. 2020, also see reviews by Eyre et al., 2014 and Lange et al., 2019].

Over both diel and seasonal time scales, NEP and NEC were highly correlated and largely positive. The correlation of NEP and NEC is most likely driven by light, through lightenhanced calcification (LEC) [Gattuso et al., 1999, and references therein]. There are various mechanisms that have been proposed to explain LEC; the most accepted involves the uptake of $\mathrm{CO}_{2}$ during photosynthesis, which elevates $\mathrm{pH}$ and $\Omega_{\mathrm{arag}}$, creating a favorable environment for calcification [Goreau and Goreau, 1959]. However, a recent study demonstrated that light enhanced calcification could be decoupled from photosynthesis at different wavelengths of light, indicating that the processes may be controlled by separate light influenced mechanisms [Cohen et al., 2016].

The Heron Island reef flat maintained largely positive NEC until dusk in 7 out of 10 months. In the early (austral) summer months of December 2015 and November 2016 the system transitioned from net calcifying to net dissolving, and no longer calcifying in February 2016, between $30-60$ min before sunset. Periods of net respiration preceded periods of net $\mathrm{CaCO}_{3}$ dissolution and there was a seasonal trend of increased net respiration earlier in the afternoon in summer months. Based on a linear relationship between temperature and respiration one would expect March and May to have highest respiration rates (or to transition to negative NEP earlier), however this was not the case. This could be due to spring organic matter storage which provides the substrate for increased respiration with high light and temperatures increasing in spring and early summer (also see Figure S3). Hansen et al. [1992] show that organic matter content of the sediments and detrital input at 
Davis reef (GBR) were highest in spring, subsequently fueling high community respiration rates in summer.

In addition, $\Omega_{\text {arag }}$ was significantly lower in December 2015 and November 2016, probably due to net respiration, which could have contributed to the early onset of dissolution (Figure S4). The late afternoon shift to net dissolution occurred despite relatively high $\Omega_{\text {arag }}$ (4.1 - 4.6) compared to other studies that have measured dissolution [Meléndez et al., 2018; Muehllehner et al., 2016]. However, $\Omega_{\text {arag }}$ was measured in the afternoon at low tide, as opposed to daytime averages, and hence expected to be high due to daytime photosynthesis drawing down DIC [Cyronak et al., 2019; Jokiel et al., 2014]. Even if bulk seawater $\Omega_{\text {arag }}$ is high, low $\Omega_{\text {arag }}$ and undersaturation of $\Omega_{\mathrm{ca}}$ in porewaters can cause dissolution in the sediments [Drupp et al., 2016; Eyre et al., 2014; Hu and Burdige, 2007], which could be the reason for the observed shift to net dissolution. It remains unknown if this late afternoon onset of negative NEC has always occurred on the Heron Island reef flat, if it is a seasonal phenomenon, or if it is a response to lower $\Omega_{\text {arag }}$ in the water column due to ongoing ocean acidification, or a combination [Cyronak et al., 2014]. A study on a nearby reef, One Tree Island, has found a 3-fold increase in nighttime dissolution since the 1970s; however, net $\mathrm{CaCO}_{3}$ dissolution was not measured until $\sim 30$ min before sunset [Silverman et al., 2012], compared to up to 60 minutes before sunset on Heron Island.

\section{The role of $\mathrm{CaCO}_{3}$ sediments in future transitions to net dissolution}

When comparing $\mathrm{NEC}_{\text {reef }}$ to $\mathrm{NCC}_{\text {sediment }}$, they show similar patterns in monthly and seasonal variation [Stoltenberg et al., 2019]. Most importantly, some of the months in which reef NEC was negative before sunset coincide with the months where highest sediment dissolution rates were measured [Stoltenberg et al., 2019]. In December, for example, our estimated contribution of $\mathrm{NCC}_{\text {sediment }}$ to reef NEC is also among the highest (78\%), indicating that the reef-wide dissolution measured in that month may be a direct result of increased rates 
of sediment dissolution (Table 1). Our estimates of $\mathrm{CaCO}_{3}$ sediments contribution to reef NEP and NEC show that the sediments are contributing proportionately more to NEC at night (44- $78 \%$ ) as opposed to during the day $(8.3-21 \%)$. The higher contribution of the sediments to NEC at night is likely due to generally lower nighttime gross biogenic calcification compared to daytime rates [Gattuso et al., 1999], which allows sediment dissolution to exert a stronger control on NEC at night. In contrast, there was not much difference between daytime and nighttime contributions of sediments to NEP, which averaged $13.5 \pm 7 \%$ and is similar to the range (3-30\%) reported for a reef in French Polynesia [Boucher et al., 1998].

With pre-industrial $\Omega_{\text {arag }}$ at the study site estimated to be around one unit higher (Table 2), the seasonal transition we observed might be due in part to ongoing ocean acidification and may be an early warning of a pending negative reef NEC. Ocean acidification will likely result in a reduction in NEC during the day driven by the reduction in coral calcification, at least for some species and communities [Albright et al., 2018; Doo et al., 2019; Langdon and Atkinson, 2005; Schneider and Erez, 2006], and a much more substantial reduction in NEC at night driven by the increase in dissolution of the sediments [Cyronak et al., 2013; Eyre et al., 2018; Fink et al., 2017]. Due to the natural diurnal cycle in coral reef NEC, we could expect the first transitions to net dissolution associated with ocean acidification to occur at night. As ocean acidification on coral reefs is expected to intensify [Cyronak et al., 2014], these transitions could spill over on both sides of the diel curve with periods of net dissolution occurring earlier in the afternoon and later into the morning (see Figure 2; Table 2). In a recent field study using a free ocean $\mathrm{CO}_{2}$ enrichment (FOCE) Doo et al. [2019] showed that OA decreased both daytime and nighttime NEC, but the effect on dissolution at night was almost twice as high. As a result of both daytime and nighttime decreases, net NEC declined by about 50\% [Doo et al. 2019]. Interestingly, the effect of OA 
on nighttime dissolution decreased over time [Doo et al. 2019], which could indicate a buffering effect of increased sediment dissolution against high $\mathrm{pCO}_{2}$ treatments. However, it is unclear if the system was fully flushed between measurements or if a build-up of alkalinity was the cause of this attenuation [Doo et al. 2019].

The reef slope and outer reef flat of Heron Island have high coral cover and are considered a healthy reef system which is consistent with high rates of NEC [Albright et al., 2016; McMahon et al. 2013; Salmond et al., 2018] and net carbonate production [Brown et al., 2020]. Coral cover and carbonate production in the inner reef flat and lagoon are significantly lower [Brown et al. 2020]. Despite this, we measured periods of net $\mathrm{CaCO}_{3}$ dissolution before dusk on Heron Island, which have not been seen before [McMahon et al., 2013, 2018; Albright et al., 2015]. It is likely that these periods of negative NEC are also occurring on reefs elsewhere, but a lack of high-resolution measurements that include these transitional periods of late afternoon and early mornings means these trends are not being detected. There have been several in situ studies of coral reef NEC that have included diel and/or seasonal cycles [Silverman et al., 2007, 2012; Shamberger et al., 2011; McMahon et al., 2013, 2018, 2019; Shaw et al., 2014; Albright et al., 2015; Davis et al., 2019; DeCarlo, 2017]. In most of these studies negative NEC does not occur before dusk or remained positive even into the night [De Carlo et al., 2017], except on a similar study on One Tree Island, Great Barrier Reef [Shaw et al., 2014]. However, none of these studies have specifically focused on the transition from positive to negative NEC and it is not always evident exactly when NEC became negative. Additionally, some of the older literature [for example Kinsey, 1978; Gattuso et al., 1996] might not be reflective of the ongoing changes we could already be seeing due to ocean acidification. We postulate that these periods of periodic net $\mathrm{CaCO}_{3}$ dissolution could be more widespread than presently thought.

This article is protected by copyright. All rights reserved. 
While the slack-water method is traditionally used for tidal pools or small areas of reef, we believe that it is valid to use this approach at Heron Island because the flow is highly unidirectional and consistent during the slack tide. The unique tidal isolation and drainage patterns on the reef flat lead to a predictable area of the reef flat that could influence changes in seawater chemistry (see Figure S1). Nonetheless, this approach comes with certain assumptions and limitations and the rates calculated here should be used with caution when comparing absolute rates (refer to the supplementary material for a more in-depth discussion on methods and limitations). Our metabolic rates compare well to previous measurements made in the same general area and a recent carbonate budget for Heron Island [Brown et al. 2020]. Platform-wide carbonate production was $4.06 \mathrm{~kg} \mathrm{CaCO}_{3} \mathrm{~m}^{-2} \mathrm{yr}^{-1}$ and $1.53 \mathrm{~kg} \mathrm{CaCO}_{3}$ $\mathrm{m}^{-2} \mathrm{yr}^{-1}$ within the reef flat which compares well with our net integrated NEC rates from November 2016 for the inner reef flat $\left(42 \mathrm{mmol} \mathrm{CaCO}_{3} \mathrm{~m}^{-2} \mathrm{~d}^{-1}\right.$ converted from Brown et al 2020 versus $65 \mathrm{mmol} \mathrm{CaCO}_{3} \mathrm{~m}^{-2} \mathrm{~d}^{-1}$; Table S2). Importantly, they showed that the reef flat was the largest contributor to platform wide sediment production $(55 \%)$. This means that the transition to afternoon dissolution we measure here (driven by -NEP and sediment dissolution) could be relevant for platform-wide carbonate budgets.

\section{5.) Conclusion}

We show that the transition to net reef dissolution on Heron Island reef flat can occur before dusk for certain times of the year, most likely driven by reductions in $\Omega_{\text {arag }}$ due to net heterotrophy and increased sediment dissolution. Projected future warming and ocean acidification will likely increase the contribution of sediments to reef NEC as the effect of ocean acidification will be higher on night dissolution than day calcification. The adverse effects of OA will be exacerbated on reefs with low coral cover and where rates of coral calcification and therefore daytime NEC are already low, as the relative contribution at night will play a more significant role if daytime rates are depressed. As such, these changes will 
not be uniform, but instead we will most likely start to see effects on reefs that are already experiencing low rates of NEC today, and in parts of the reef with the most sediments.

The late afternoon seasonal transition to negative NEC, as seen on the Heron Island reef flat in certain times of the year, may be an early warning of a pending negative reef NEC. Other reefs with higher NEC will most likely start to show the first signs of periodic net dissolution in the late afternoon, which could lead to seasonal transitions to net dissolution over a diel cycle, eventually transitioning to net dissolution over an annual cycle. In the context of future ocean acidification, warming, and sea-level rise, the reductions of $\mathrm{NCC}_{\text {sediments }}$ could further contribute to reductions in reef NEC and lead to loss of reef sediments and reef framework with potential declines in structural complexity, which could have far-reaching impacts and cascading effects for coral reef ecosystem functioning.

\section{Data availability statement}

In accordance with FAIR data principles, the data set to produce the figures and analyses in this manuscript was uploaded to Zenodo (available at https://doi.org/10.5281/zenodo.4291744).

\section{Acknowledgements}

The authors would like to thank Daniel Trnovsky, Jacob Yeo, Jessica Rickenberg, Marc Jordan, and Elisabeth Deschaseaux for assistance in the field. Bronte Tilbrook kindly provided the SeapHOx sensor for monitoring environmental data. We thank the staff at Heron Island Research Station. Research was carried out under the Great Barrier Reef Marine Park Authority Permit G1Q6/38438.1. An ARC Discovery Grant DP150102092 awarded to B.D.E. and K.G.S. provided funding for this research. Data is available at https://doi.org/10.5281/zenodo.4291744.

\section{Author contributions}

This article is protected by copyright. All rights reserved. 
B.D.E., K.G.S. and L.S. conceived the project, L.S. carried out the field work and analyzed the samples and data. All authors assisted with the field work. L.S. wrote the manuscript with input from all co-authors. All authors approved the final manuscript.

This article is protected by copyright. All rights reserved. 
References

Albright, R., J. Benthuysen, N. Cantin, K. Caldeira, and K. Anthony (2015), Coral reef metabolism and carbon chemistry dynamics of a coral reef flat, Geophysical Research Letters, 42(10), 3980-3988.

Albright, R., Y. Takeshita, D. A. Koweek, A. Ninokawa, K. Wolfe, T. Rivlin, Y. Nebuchina, J. Young, and K. Caldeira (2018), Carbon dioxide addition to coral reef waters suppresses net community calcification, Nature, 555(7697), 516-519.

Alvarez-Filip, L., N. Dulvy, J. Gill, I. Côté, and A. Watkinson (2009), Flattening of Caribbean coral reefs: Region-wide declines in architectural complexity, Proceedings. Biological sciences / The Royal Society, 276, 3019-3025.

Allen Coral Atlas Partnership and Vulcan, Inc. (2019), Heron Island benthic analysis, accessed online on 11 November 2019. Available from www.allencoralatlas.org.

Andersson, A. J., I. B. Kuffner, F. T. Mackenzie, P. L. Jokiel, K. S. Rodgers, and A. Tan (2009), Net Loss of $\mathrm{CaCO} 3$ from a subtropical calcifying community due to seawater acidification: mesocosm-scale experimental evidence, Biogeosciences, 6(8), 1811-1823.

Atkinson, M. J. (2011), Biogeochemistry of Nutrients, in Coral Reefs: An Ecosystem in Transition, edited by Z. Dubinsky and N. Stambler, pp. 199-206, Springer Netherlands, Dordrecht.

Bates, N., A. A, and A. Andersson (2009), The interaction of ocean acidification and carbonate chemistry on coral reef calcification: evaluating the carbonate chemistry Coral Reef Ecosystem Feedback (CREF) hypothesis on the Bermuda coral reef, Biogeosciences Discussions, 6.

Bates, N. R., A. Amat, and A. J. Andersson (2010), Feedbacks and responses of coral calcification on the Bermuda reef system to seasonal changes in biological processes and ocean acidification, Biogeosciences, 7(8), 2509-2530.

Bates, D. Maechler, M. Bolker, B. and S. Walker (2015). Fitting Linear Mixed-Effects Models Using Ime4. Journal of Statistical Software, 67(1), 1-48.

Bresnahan, P. J., T. R. Martz, Y. Takeshita, K. S. Johnson, and M. LaShomb (2014), Best practices for autonomous measurement of seawater $\mathrm{pH}$ with the Honeywell Durafet, Methods in Oceanography, 9, 44-60.

Boucher, G., J. Clavier, C. Hily, and J.-P. Gattuso (1998), Seawater carbonate chemistry and calcification during a study of barrier reef flat in Moorea, French Polynesia, 1998, in Supplement to: Boucher, $G$ et al. (1998): Contribution of soft-bottoms to the community metabolism (primary production and calcification) of a barrier reef flat (Moorea, French Polynesia). Journal of Experimental Marine Biology and Ecology, 225(2), 269-283, https://doi.org/10.1016/S0022-0981(97)00227-X, edited, PANGAEA.

Brandl, S. J. (2019), Big data guides pragmatic management, Nature Ecology \& Evolution, 3(9), 1283-1284.

Burdige, D. J., X. Hu, and R. C. Zimmerman (2010), The widespread occurrence of coupled carbonate dissolution/reprecipitation in surface sediments on the Bahamas Bank, American Journal of Science, 310(6), 492-521.

Carpenter, R., C. Lantz, E. Shaw, and P. Edmunds (2018), Responses of coral reef community metabolism in flumes to ocean acidification, Marine Biology, 165, 66.

Cohen, I., Z. Dubinsky, and J. Erez (2016), Light Enhanced Calcification in Hermatypic Corals: New Insights from Light Spectral Responses, Frontiers in Marine Science, 2(122).

This article is protected by copyright. All rights reserved. 
Comeau, S., R. C. Carpenter, C. A. Lantz, and P. J. Edmunds (2015), Ocean acidification accelerates dissolution of experimental coral reef communities, Biogeosciences, 12(2), 365372.

Cooper, T. F., G. De'Ath, K. E. Fabricius, and J. M. Lough (2008), Declining coral calcification in massive Porites in two nearshore regions of the northern Great Barrier Reef, Global Change Biology, 14(3), 529-538.

Courtney, T. A., et al. (2016), Comparing Chemistry and Census-Based Estimates of Net Ecosystem Calcification on a Rim Reef in Bermuda, Frontiers in Marine Science, 3, 181. Courtney, T. A., and A. J. Andersson (2019), Evaluating measurements of coral reef net ecosystem calcification rates, Coral Reefs.

Cyronak, T., I. R. Santos, and B. D. Eyre (2013), Permeable coral reef sediment dissolution driven by elevated pCO2 and pore water advection, Geophysical Research Letters, 40(18), 4876-4881.

Cyronak, T., K. G. Schulz, I. R. Santos, and B. D. Eyre (2014), Enhanced acidification of global coral reefs driven by regional biogeochemical feedbacks, Geophysical Research Letters, 41(15), 5538-5546.

Cyronak, T., and B. D. Eyre (2016), The synergistic effects of ocean acidification and organic metabolism on calcium carbonate ( $\mathrm{CaCO} 3$ ) dissolution in coral reef sediments, Marine Chemistry, 183, 1-12.

Cyronak, T., et al. (2019), Diel temperature and pH variability scale with depth across diverse coral reef habitats, Limnology and Oceanography Letters, $n / a(n / a)$.

Davis, K. L., A. McMahon, B. Kelaher, E. Shaw, and I. R. Santos (2019), Fifty Years of Sporadic Coral Reef Calcification Estimates at One Tree Island, Great Barrier Reef: Is it Enough to Imply Long Term Trends?, Frontiers in Marine Science, 6(282).

DeCarlo, T. M., A. L. Cohen, G. T. F. Wong, F.-K. Shiah, S. J. Lentz, K. A. Davis, K. E. F. Shamberger, and P. Lohmann (2017), Community production modulates coral reef pH and the sensitivity of ecosystem calcification to ocean acidification, Journal of Geophysical Research: Oceans, 122(1), 745-761.

Dickson, A. G., and F. J. Millero (1987), A comparison of the equilibrium constants for the dissociation of carbonic acid in seawater media, Deep Sea Research Part A. Oceanographic Research Papers, 34(10), 1733-1743.

Dickson, A., C. Sabine, and J. Christian (2007), Guide to Best Practices for Ocean CO2 MeasurementsRep., 191 pp, PICES Special Publication.

Doo, S. S., P. J. Edmunds, and R. C. Carpenter (2019), Ocean acidification effects on in situ coral reef metabolism, Scientific Reports, 9(1), 12067.

Drupp, P. S., E. H. De Carlo, and F. T. Mackenzie (2016), Porewater CO2-carbonic acid system chemistry in permeable carbonate reef sands, Marine Chemistry, 185, 48-64. Eyre, B. D., and D. Pont (2003), Intra- and inter-annual variability in the different forms of diffuse nitrogen and phosphorus delivered to seven sub-tropical east Australian estuaries, Estuarine, Coastal and Shelf Science, 57(1), 137-148.

Eyre, B. D., A. J. Andersson, and T. Cyronak (2014), Benthic coral reef calcium carbonate dissolution in an acidifying ocean, Nature Climate Change, 4, 969.

Eyre, B. D., T. Cyronak, P. Drupp, E. H. De Carlo, J. P. Sachs, and A. J. Andersson (2018), Coral reefs will transition to net dissolving before end of century, Science, 359(6378), 908-911. Fink, A., J. den Haan, A. Chennu, S. Uthicke, and D. de Beer (2017), Ocean Acidification Changes Abiotic Processes but Not Biotic Processes in Coral Reef Sediments, Frontiers in Marine Science, 4(73).

This article is protected by copyright. All rights reserved. 
Gardner, T., I. Côté, J. Gill, A. Grant, and A. Watkinson (2003), Long-term Regional-wide declining in Caribbean corals, Science (New York, N.Y.), 301, 958-960.

Gattuso, J.-P., M. Pichon, and B. Delesalle (1993), Community metabolism and air-sea CO2 fluxes in a coral reef ecosystem (Moorea, French Polynesia), Marine Ecology Progress Series, 96, 259-267.

Gattuso, J.-P., M. Frankignoulle, and R. Wollast (1998), CARBON AND CARBONATE METABOLISM IN COASTAL AQUATIC ECOSYSTEMS, Annual Review of Ecology and Systematics, 29(1), 405-434.

Gattuso, J.-P., D. Allemand, and M. Frankignoulle (1999), Photosynthesis and Calcification at Cellular, Organismal and Community Levels in Coral Reefs: A Review on Interactions and Control by Carbonate Chemistry, American Zoologist, 39(1), 160-183.

Goreau, T. F., and N. I. Goreau (1959), The Physiology Of Skeleton Formation In Corals. II. Calcium Deposition By Hermatypic Corals Under Various Conditions In The Reef, The Biological Bulletin, 117(2), 239-250.

Graham, N. A. J., and K. L. Nash (2013), The importance of structural complexity in coral reef ecosystems, Coral Reefs, 32(2), 315-326.

$\mathrm{Hu}, \mathrm{X}$. , and D. Burdige (2007), Enriched stable carbon isotopes in the pore waters of carbonate sediments dominated by seagrasses: Evidence for coupled carbonate dissolution and reprecipitation, Geochimica et Cosmochimica Acta, 71.

Hughes, T. P., et al. (2018), Global warming transforms coral reef assemblages, Nature, 556(7702), 492-496.

IPCC (2014), Climate Change 2014: Synthesis Report. Contribution of Working Groups I, II and III to the Fifth Assessment Report of the Intergovernmental Panel on Climate Change [Core Writing Team, R.K. Pachauri and L.A. Meyer (eds.)]Rep., 151 pp, Geneva, Switzerland. Jiang, Z.-P., T. Tyrrell, D. J. Hydes, M. Dai, and S. E. Hartman (2014), Variability of alkalinity and the alkalinity-salinity relationship in the tropical and subtropical surface ocean, Global Biogeochemical Cycles, 28(7), 729-742.

Jokiel, P. L., C. P. Jury, and K. u. S. Rodgers (2014), Coral-algae metabolism and diurnal changes in the CO2-carbonate system of bulk sea water, PeerJ, 2, e378.

Kinsey, D. W. (1978), Alkalinity changes and coral reef calcification1, Limnology and Oceanography, 23(5), 989-991.

Kline, D. I., et al. (2019), Living coral tissue slows skeletal dissolution related to ocean acidification, Nature Ecology \& Evolution, 3(10), 1438-1444.

Langdon, C., and M. J. Atkinson (2005), Effect of elevated pCO2on photosynthesis and calcification of corals and interactions with seasonal change in temperature/irradiance and nutrient enrichment, Journal of Geophysical Research, 110(C9).

Langdon, C., J.-P. Gattuso, and A. J. Andersson (2010), Measurements of calcification and dissolution of benthic organisms and communities, edited, pp. 213-234.

Lange, I., C. Perry, and L. Alvarez-Filip (2019), Carbonate budgets as indicators of functional reef "health": A critical review of data underpinning census-based methods and current knowledge gaps, Ecological Indicators, 110, 105857.

Lê, S., Josse, J. \& Husson, F. (2008). FactoMineR: An R Package for Multivariate Analysis. Journal of Statistical Software. 25(1). pp. 1-18.

Martz, T. R., J. G. Connery, and K. S. Johnson (2010), Testing the Honeywell Durafet ${ }^{\circledR}$ for seawater pH applications, Limnology and Oceanography: Methods, 8(5), 172-184.

This article is protected by copyright. All rights reserved. 
McMahon, A., I. R. Santos, T. Cyronak, and B. D. Eyre (2013), Hysteresis between coral reef calcification and the seawater aragonite saturation state, Geophysical Research Letters, 40(17), 4675-4679.

McMahon, A., I. R. Santos, K. G. Schulz, T. Cyronak, and D. T. Maher (2018), Determining coral reef calcification and primary production using automated alkalinity, $\mathrm{pH}$ and $\mathrm{pCO} 2$ measurements at high temporal resolution, Estuarine, Coastal and Shelf Science, 209, 80-88. McMahon, A., I. R. Santos, K. G. Schulz, A. Scott, J. Silverman, K. L. Davis, and D. T. Maher (2019), Coral Reef Calcification and Production After the 2016 Bleaching Event at Lizard Island, Great Barrier Reef, Journal of Geophysical Research: Oceans, 0(0).

Mehrbach, C., C. H. Culberson, J. E. Hawley, and R. M. Pytkowicx (1973), Measurement of the apparent dissociation constants of carbonic acid in seawater at atmospheric pressure, Limnology and Oceanography, 18(6), 897-907.

Meléndez, M., J. Salisbury, D. Gledhill, C. Langdon, J. M. Morell, D. Manzello, S. Musielewicz, and A. Sutton (2018), Seasonal Net Ecosystem Metabolism of the Near-Shore Reef System in La Parguera, Puerto Rico, Biogeosciences Discuss., 2018, 1-50.

Muehllehner, N., C. Langdon, A. Venti, and D. Kadko (2016), Dynamics of carbonate chemistry, production, and calcification of the Florida Reef Tract (2009-2010): Evidence for seasonal dissolution, Global Biogeochemical Cycles, 30(5), 661-688.

Perry, C. T., et al. (2018), Loss of coral reef growth capacity to track future increases in sea level, Nature, 558(7710), 396-400.

Pisapia, C., E. J. Hochberg, and R. Carpenter (2019), Multi-Decadal Change in Reef-Scale Production and Calcification Associated With Recent Disturbances on a Lizard Island Reef Flat, Frontiers in Marine Science, 6(575).

R Development Core Team (2015), R: A language and environment for statistical computing, edited, R Foundation for Statistical Computing, Vienna, Australia.

Reynaud, S., N. Leclercq, S. Romaine-Lioud, C. Ferrier-PagËs, J. Jaubert, and J.-P. Gattuso (2003), Seawater carbonate chemistry, photosynthesis, respiration and calcification during experiments with scleractinian coral Stylophora pistillata, 2003, in In supplement to: Reynaud, S et al. (2003): Interacting effects of CO2 partial pressure and temperature on photosynthesis and calcification in a scleractinian coral. Global Change Biology, 9(11), 16601668, https://doi.org/10.1046/j.1365-2486.2003.00678.x, edited, PANGAEA.

Schneider, K., and J. Erez (2006), The effect of carbonate chemistry on calcification and photosynthesis in the hermatypic coral Acropora eurystoma, Limnology and Oceanography, 51(3), 1284-1293.

Shamberger, K. E. F., R. A. Feely, C. L. Sabine, M. J. Atkinson, E. H. DeCarlo, F. T. Mackenzie, P. S. Drupp, and D. A. Butterfield (2011), Calcification and organic production on a Hawaiian coral reef, Marine Chemistry, 127(1), 64-75.

Shaw, E. C., B. I. McNeil, and B. Tilbrook (2012), Impacts of ocean acidification in naturally variable coral reef flat ecosystems, Journal of Geophysical Research: Oceans, 117(C3).

Shaw, E. C., S. R. Phinn, B. Tilbrook, and A. Steven (2014), Comparability of Slack Water and Lagrangian Flow Respirometry Methods for Community Metabolic Measurements, PloS one, 9(11), e112161.

Silverman, J., B. Lazar, and J. Erez (2007), Effect of aragonite saturation, temperature, and nutrients on the community calcification rate of a coral reef, Journal of Geophysical

Research, 112(C5).

This article is protected by copyright. All rights reserved. 
Silverman, J., D. I. Kline, L. Johnson, T. Rivlin, K. Schneider, J. Erez, B. Lazar, and K. Caldeira (2012), Carbon turnover rates in the One Tree Island reef: A 40-year perspective, Journal of Geophysical Research: Biogeosciences, 117(G3).

Stoltenberg, L., K. G. Schulz, T. Cyronak, and B. D. Eyre (2019), Seasonal variability of calcium carbonate precipitation and dissolution in shallow coral reef sediments, Limnology and Oceanography, 65(4), 876-891.

Takeshita, Y., W. McGillis, E. M. Briggs, A. L. Carter, E. M. Donham, T. R. Martz, N. N. Price, and J. E. Smith (2016), Assessment of net community production and calcification of a coral reef using a boundary layer approach, Journal of Geophysical Research: Oceans, 121(8), 5655-5671.

Van Heuven, S., D. Pierrot, J.W.B. Rae, E. Lewis, and D.W.R. Wallace (2011), MATLAB Program Developed for CO2 System Calculations. ORNL/CDIAC-105b. Carbon Dioxide Information Analysis Center, Oak Ridge National Laboratory, U.S. Department of Energy, Oak Ridge, Tennessee. doi: 10.3334/CDIAC/otg.CO2SYS_MATLAB_v1.1.

Wanninkhof, R. (1992), Relationship between wind speed and gas exchange over the ocean, Journal of Geophysical Research: Oceans, 97(C5), 7373-7382.

Webb, G. E. (2001), Biologically Induced Carbonate Precipitation in Reefs through Time, in The History and Sedimentology of Ancient Reef Systems, edited by G. D. Stanley, pp. 159203, Springer US, Boston, MA.

Wickham. H (2016), ggplot2: Elegant Graphics for Data Analysis. Springer-Verlag New York. Wurgaft, E., Z. Steiner, B. Luz, and B. Lazar (2016), Evidence for inorganic precipitation of CaCO3 on suspended solids in the open water of the Red Sea, Marine Chemistry, 186, 145155.

Yates, K. K., and R. B. Halley (2006), Diurnal variation in rates of calcification and carbonate sediment dissolution in Florida Bay, Estuaries and Coasts, 29(1), 24-39.

Yeakel, K. L., A. J. Andersson, N. R. Bates, T. J. Noyes, A. Collins, and R. Garley (2015), Shifts in coral reef biogeochemistry and resulting acidification linked to offshore productivity, Proceedings of the National Academy of Sciences, 112(47), 14512.

This article is protected by copyright. All rights reserved. 


\section{Table 1}

Contribution (\%) of $N C C_{\text {sediments }}$ and $N C P_{\text {sediments }}$ to $N E C$ and NEP of the reef flat.

\begin{tabular}{|c|c|c|c|c|}
\hline Month & $\begin{array}{c}\text { NEC } \\
\text { afternoon }\end{array}$ & $\begin{array}{c}\text { NEP } \\
\text { afternoon }\end{array}$ & $\begin{array}{l}\text { NEC } \\
\text { night }\end{array}$ & $\begin{array}{l}\text { NEP } \\
\text { night }\end{array}$ \\
\hline Oct-15 & 12.17 & 14.40 & -- & 11.26 \\
\hline Nov-15 & 9.06 & 12.86 & -- & -- \\
\hline Dec-15 & 8.29 & 24.18 & 78.23 & 14.31 \\
\hline Feb-16 & 20.76 & 25.00 & -- & 12.73 \\
\hline Mar-16 & 21.12 & 14.13 & -- & 19.13 \\
\hline May-16 & 10.81 & 11.41 & -- & -- \\
\hline Jul-16 & 8.17 & 6.06 & -- & 13.82 \\
\hline Aug-16 & 10.43 & 6.58 & -- & 18.44 \\
\hline Oct-16 & 9.42 & 6.53 & -- & 31.88 \\
\hline Nov-16 ${ }^{a}$ & 11.36 & 17.08 & 44.44 & 11.54 \\
\hline
\end{tabular}

${ }^{a}$ Percent contribution calculated from integrated rates of daytime and nighttime NEC and NEP from a diel cycle.

\section{Table 2}

Comparison of pre-industrial, present day, and future $\Omega_{\text {arag }}$ estimated using DIC concentrations of past, present and future $\mathrm{fCO}_{2}$. See supplementary material for details on calculations. Highlighted area denotes months where negative NEC was measured before dusk.

\begin{tabular}{|c|c|c|c|c|}
\hline Season & Month & $\boldsymbol{\Omega}$ arag pre-industrial & $\boldsymbol{\Omega}_{\text {arag }}$ & $\Omega_{\text {arag RCP } 8.5}$ \\
\hline \multirow[t]{4}{*}{ Spring } & Oct'15 & 5.27 & 4.37 & 3.06 \\
\hline & Nov'15 & 5.76 & 4.52 & 3.42 \\
\hline & Oct'16 & 5.67 & 4.57 & 3.43 \\
\hline & Nov'16 & 4.91 & 4.09 & 2.69 \\
\hline \multirow[t]{2}{*}{ Summer } & Dec'15 & 4.85 & 4.06 & 2.59 \\
\hline & Feb'16 & 5.00 & 4.29 & 2.76 \\
\hline \multirow[t]{2}{*}{ Autumn } & Mar'16 & 5.35 & 4.50 & 3.13 \\
\hline & May'16 & -- & -- & -- \\
\hline \multirow[t]{2}{*}{ Winter } & Jul '16 & 5.29 & 4.18 & 3.19 \\
\hline & Aug '16 & 5.24 & 4.39 & 3.09 \\
\hline
\end{tabular}

This article is protected by copyright. All rights reserved. 


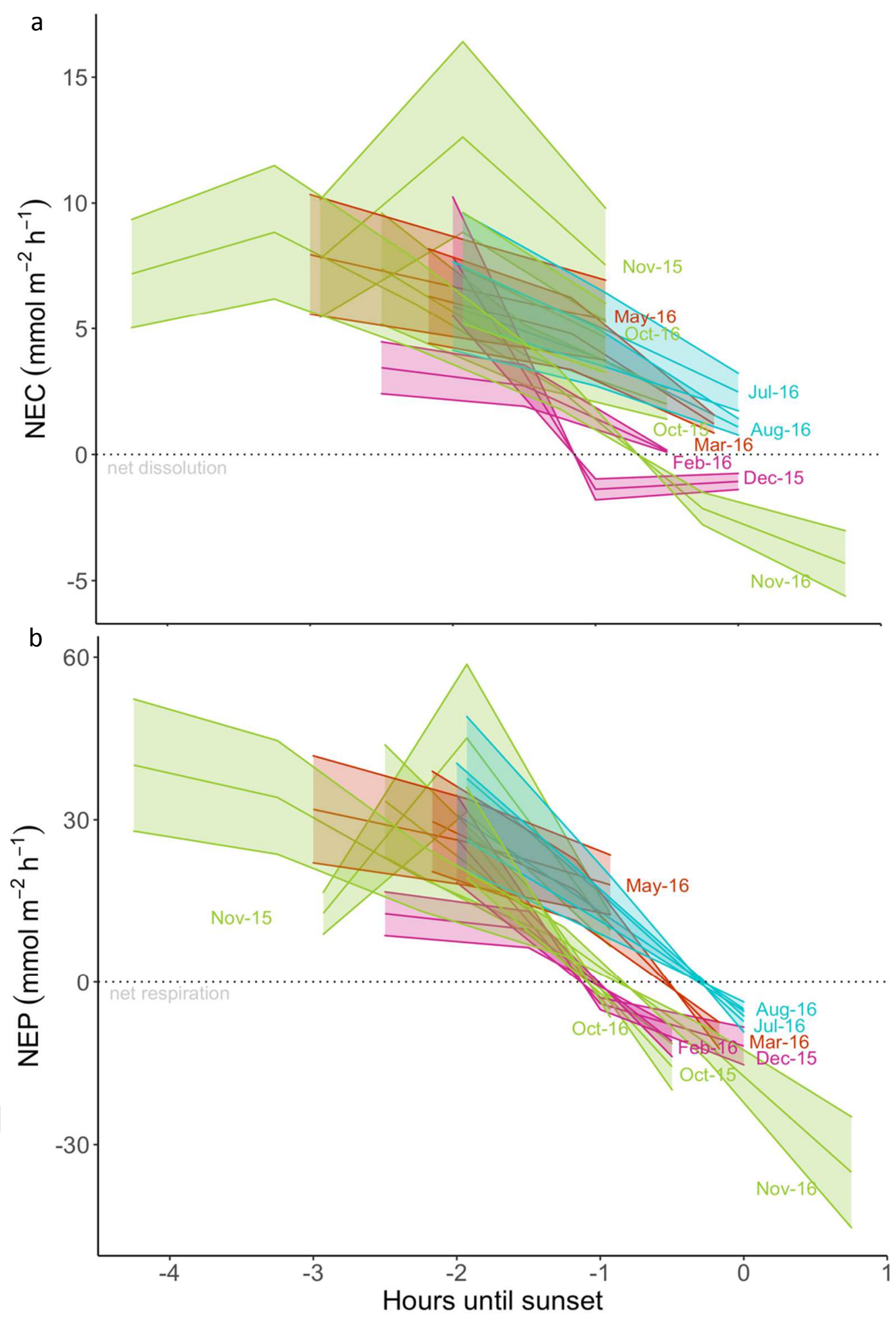

Figure 1 - Afternoon rates of NEC $\left(\mathrm{mmol} \mathrm{CaCO}_{3} \mathrm{~m}^{-2} \mathrm{~h}^{-1}\right)(\mathrm{a})$ and $\mathrm{NEP}\left(\mathrm{mmol} \mathrm{O} \mathrm{m}^{-2} \mathrm{~h}^{-1}\right)(\mathrm{b})$ for different months of the year with black horizontal dashed lines indicating transition to net dissolution and net respiration, respectively. Shaded areas represent the minimum and maximum NEC and NEP calculated with a $30 \%$ uncertainty in depth measurements. 


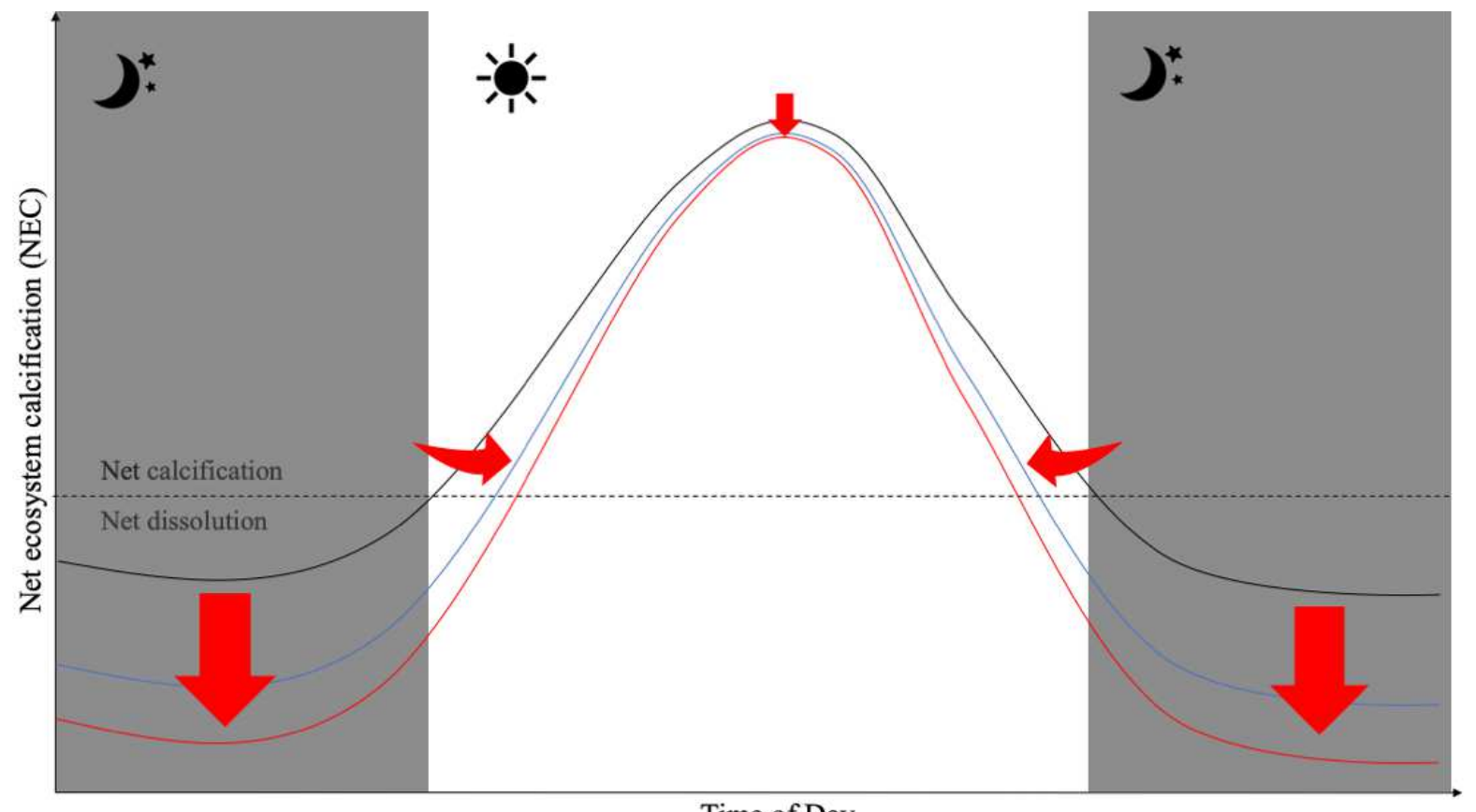

Time of Day

Figure 2 - Conceptual diagram of sediment contribution to net ecosystem calcification illustrating how ocean acidification could shape the relationship of NEC versus time of day to favor an early onset of dissolution accounting for the higher relative contribution of sediment dissolution at night. The black line represents NEC, the blue line represents the present-day contribution of sediment net community calcification to NEC, and the red line represents the estimated contribution of sediments with future ocean acidification. Red arrows highlight the differences in expected shifts in contributions during the day and night, as well as shifts in the onset of net calcification and net dissolution over a diel cycle.

This article is protected by copyright. All rights reserved. 